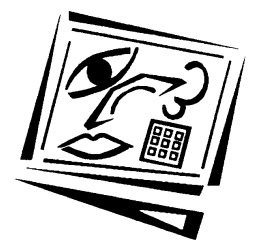

\title{
Reasons for using or not using interactive whiteboards: Perspectives of Taiwanese elementary mathematics and science teachers
}

\author{
Syh-Jong Jang and Meng-Fang Tsai \\ Chung-Yuan Christian University
}

\begin{abstract}
This study examines the reasons for using or not using interactive whiteboards (IWBs) by elementary school mathematics and science teachers in Taiwan. It also considers whether there were any significant differences in the reasons according to teaching subjects, teacher gender, and teaching experience. The survey was developed based on an overview of the discussions from prior research related to the benefits and drawbacks in using IWBs. Percentages were high on all six reasons for using IWBs. Of the five reasons for not using IWBs, budget constraints appeared to be the most important reason why the teachers did not use IWBs in their classroom. Male teachers using IWBs showed significantly higher ratings than female teachers for getting students' attention and increasing interaction. Experienced teachers' ratings were significantly higher than novice teachers for getting students' attention, helping teachers explain complex and abstract concepts, and helping the teaching process. In the group of teachers who reported not using IWBs, male teachers showed significantly higher ratings for the lack of time to design teaching materials, and limited sources of related teaching software. Research implications of this study are provided along with suggestions for future study.
\end{abstract}

\section{Introduction}

Information and communication technology has been emphasised as an important concept in education, by which teaching effectiveness can be improved to enhance students' learning through the use of technological devices. The interactive whiteboard (IWB) is one of the technological tools that have become widely used by school teachers in many countries. Researchers have discussed the advantages and drawbacks of using IWBs in different contexts (Miller \& Glover, 2002; Schmid, 2008; Slay, Sieborger \& Hodgkinson-Williams, 2008; Smith, Higgins, Wall \& Miller, 2005). In Taiwan, the Ministry of Education (2008) has allocated funds to purchase this device for a number of schools to encourage school teachers to use it and increase teaching effectiveness. But following this promotion, little is known of elementary school teachers' use of IWBs and why they chose to integrate or not to integrate them into their teaching.

Researchers have studied teachers' pedagogical approaches with the use of IWBs in different domains, such as literacy (Shenton \& Pagett, 2007), science (Hennessy, Deaney, Ruthven \& Winterbottom, 2007; Jang \& Tsai, 2012; Murcia \& Sheffield, 2010) and mathematics (Miller, Glover \& Averis, 2005). The findings indicated that teachers developed various teaching strategies for integrating IWBs into their teaching to increase their interactions with students (Miller, Glover \& Averis, 2005), to smooth the 
teaching process (Smith et al., 2005), to help explain complex concepts (Lopez, 2010) and maintain students' attention (Wall, Higgins \& Smith, 2005), and to increase the opportunities for adapting other classroom materials (Miller et al., 2005). Some researchers also showed that teachers perceived reasons for not using IWBs including not having an IWB installed in each classroom (Slay et al., 2008), lack of time to design instructional lessons (Higgins, Beauchamp \& Miller, 2007), lack of professional training and related teaching software, as well as difficulties in solving technological problems (Slay et al., 2005). According to these results, teachers have various reasons to use or not to use IWBs.

Current studies on the reasons for using or not using IWBs have mainly used qualitative data. There has been little research conducted that employs quantitative measures to examine teachers' reasons for using or not using IWBs, as well as whether the reasons are related to teachers' teaching subjects, gender, or teaching experience. We also recognise the need to examine elementary school teachers' use of IWBs and their reasons to use or not use IWBs following the promotion of their use by the Taiwan Ministry of Education (2008). For this study, we first reviewed prior empirical research on the advantages and drawbacks of using IWBs and categorised these advantages and drawbacks into reasons for survey purposes, for elementary school teachers to rate. The results of this study can provide researchers, policy makers, and school administrators with a better understanding of elementary school teachers' perspectives on these reasons. Therefore, the study used a survey to examine elementary school mathematics and science teachers' reasons for using or not using IWBs in Taiwan. In each group (i.e., use versus no use of IWBs), the significance of each reason was further examined according to the teachers' instructional subjects, gender, and teaching experiences.

\section{Related literature}

\section{Information and communication technology - use of interactive whiteboards}

A number of studies on ICT tools used in education have been conducted to understand the development of teachers' ICT skills, such as relationships between school teachers' ICT skills, their pedagogical thinking and classroom practices (Hakkarainen, Muukonen, Lipponeni, Ilomaki, Rahikainen \& Lehtinen, 2001), preservice teachers' development of web pages (da Ponte, Oliveira \& Varandas, 2002), and integration of ICT in different academic subjects (Sutherland et al., 2004). Sutherland et al. stated the importance of choosing ICT tools to fit different classroom cultures, for which each technological tool needs to be selected within a particular socio-cultural setting and its functions need to be appropriately integrated into the subject content. Internet and web based learning systems are becoming essential to create interaction and communication between teachers' teaching and students' learning (Chou, 2003; Jang, 2009). The IWB is one of the ICTs widely used in school settings to increase these interactions and develop teachers' pedagogical strategies by integrating the features of this particular device into teaching (Higgins et al., 2007; Kennewell, Tanner, Jones \& Beauchamp, 2008). The processes of teachers integrating IWBs are to provide students with positive learning outcomes.

IWBs support different teaching and learning styles since IWBs have special features different from traditional blackboards, in that IWBs are equipped with the functions of capturing, emphasising, storing, annotating and modifying, and linking (Beauchamp 
\& Parkinson, 2005). The IWB can serve as a facilitative technological tool in classroom to promote teaching effectiveness and to help teachers develop various pedagogical approaches with this technological integration (Jang \& Tsai, 2012; Winzenried, Dalgarno \& Tinkler, 2010). The integration of its functions into pedagogical strategies to improve teaching effectiveness has been studied with pre-service teachers (Murcia, 2008) and with in-service teachers for science (Hennessy, Deaney, et al., 2007; Jang, 2010; Murcia \& Sheffield, 2010; Warwick, Mercer, Kershner \& Staarman, 2010) and mathematics (Miller et al., 2005). Beauchamp (2004) stated that in the transition process from traditional methods, teachers require several developmental stages involved with continual progress to integrate this technological device into their pedagogical approaches.

Murcia and Sheffield (2010) studied four elementary science teachers' classroom discourse through their integrative use of IWBs in an inquiry-based learning environment. Participating teachers received expert input from the researchers and technology consultants, as well as three sessions of professional trainings at the initial stage of the project. These sessions covered implementing instructional skills in the inquiry-based science learning environment, development of IWB skills, and discourse to support learning through scientific inquiry. Researchers also developed an online resource site to continue supporting teachers' professional learning and to provide sources for technology use. A mid-point meeting was held for teachers to reflect on their actual practices and adjust their teaching approaches if necessary. A final meeting was held with participating teachers, technology consultants, and representatives of the schools to provide opportunities for participating teachers to share their interactive teaching approaches with IWBs and the learning process of practicing the approaches in their classroom. Video data was collected before and during the use of IWBs in scientific inquiry lessons. Video-recorded lessons prior to the project served as a baseline for data analyses. Comparisons of the data on the pre-IWB and post-IWB use indicated that the use of IWBs increased interactive discourse in students' communication. When teachers used IWBs, they were more likely to require students to participate in discussions, use more open-ended questions, and extend waiting time for their students to think and process the information. In this particular learning environment, students produced higher quality discourse as they increased their discussion related to argumentation-reasoning and exploration in science learning.

Other researchers further examined how the integration of IWB in teaching can enhance students' comprehension of mathematical thinking (Merrett \& Edwards, 2005; Taylor, Harlow, \& Forret, 2010), motivation (Beauchamp \& Parkinson, 2005; Hall \& Higgins, 2005; Miller \& Glover, 2002; Schmid, 2008) and performances (Lopez, 2010). Therefore, the use of IWBs has been evidenced to positively influence teachers' integrative skills, with developing their pedagogical approaches and students' learning as associated outcomes.

However, other researchers found some challenges in using IWBs, including the cost of installing an IWB, the time it takes teachers to prepare classroom lessons, and inappropriate use of the IWB causing students' confusion on learning contents (Miller \& Glover, 2002; Schmid, 2008). Miller and Glover (2002) examined benefits and problems of using IWBs with 35 elementary teachers. The data were obtained from a questionnaire including closed and open-ended questions, and participating teachers' comments, classroom observations and interviews. Limiting the benefits of using IWBs, teachers reported that they did not have sufficient time to design classroom lessons and materials to help them successfully use IWBs in teaching. In addition, 
teachers reported the difficulty of not having a technical consultant available to help with their immediate needs in solving technical problems when using IWBs in their classroom.

In prior studies on the use of IWBs, benefits and drawbacks have mostly been discussed on the basis of qualitative data analyses. We reviewed the research related to the benefits and drawbacks of the use of IWBs from prior empirical studies, and incorporated the reasons for using or not using IWBs into a survey. This was used to examine Taiwanese elementary school mathematics and science teachers' ratings for their reasons. The following section provides a discussion on how each reason included in the survey was derived from prior empirical studies.

\section{Reasons for using and not using interactive whiteboards}

A growing number of studies are now available to understand the integration of technology into pedagogy. In some of these studies, researchers have found that teachers' use of IWBs can increase student motivation (Glover, Miller, Averis \& Door, 2007; Hall \& Higgins, 2005; Hennessy, Deaney, et al., 2007; Schmid, 2008; Slay et al., 2008; Torff \& Tirotta, 2010) and performance (Lopez, 2010). Furthermore, IWBs are expected to enhance both teaching quality and learning efficiency. For the aims of this study, the reasons for using or not using IWBs have been identified from reviewing prior empirical studies. The survey items of these reasons were numbered, and the numbers are stated along with the references to prior empirical studies in the following literature review (Table 1). The numbered survey items included six closed-ended questions to indicate the reasons for using IWBs and five closed-ended questions to indicate the reasons for not using IWBs. The IWB is an innovative teaching tool that is designed to replace school traditional blackboards. Since they do not produce chalk dust, they are good for the environment and human health (Arnott, 2004; Reason 4). Various groups of researchers have worked with the relationship between the use of IWBs and their impact on teaching (Glover, Miller, Averis, \& Door, 2005; Holmes, 2009; Jang, 2010; Shenton \& Pagett, 2007). Smith et al. (2005) have identified several potential benefits for teachers to flexibly integrate IWBs into developing a variety of pedagogical approaches, and the power to efficiently deliver multimedia or multimodal presentations with a touch sensitive screen (Reason 3).

Another benefit is the integration of interactive electronic whiteboard and multimedia technologies (Gillen, Littleton, Twiner, Staarman \& Mercer, 2008). Miller et al. (2005) used an exhibition platform of real items for instant digitisation. These items were projected onto an interactive electronic whiteboard, which allowed for annotations of the e-teaching materials (Reason 6). The complete instructional process can be automatically saved in an electronic notebook, easily stored for usage and after-class review. This type of new instruction emphasises "bilateral interaction" in which the proposed questions are used to clarify problems or understand the learning outcomes for students. The instant feedback system can be used to quickly achieve the learning objective of bilateral interaction between teachers and students (Miller et al., 2005; Reason 5). IWBs can lead students into a process of internalising knowledge, by offering available multimedia, simulations, and modeling for students to improve their understanding of abstract concepts (Lopez, 2010; Reason 2).

Moreover, many teachers consider the potential of the IWB to be more than a teacher's resource box (Warwick \& Kershner, 2008) that is better able to capture and hold the learners' attention, thereby leading to increased students' motivation (Miller \& Glover, 
2002; Wall et al., 2005; Reason 1), and the ability to teach at a faster pace (Gillen et al., 2008; Shenton \& Pagett, 2007; Smith, Hardman \& Higgins, 2006). Beyond this, students' positive outcomes are more likely to be attained when teachers are able to unify the performance of the IWB technology into their existing instructional approaches. In addition, the use of IWBs supports teachers' processes of designing lessons and developing teaching resources for designated learning contents (Reason 6). It also allows teachers to design proper technology skills for their students and improves interactivity and student participation in lessons (Hennessy, Wishart, et al., 2007; Holmes, 2009; Reason 5).

Table 1: Reasons for using or not using interactive whiteboards

\begin{tabular}{|c|c|c|c|}
\hline & & & $\begin{array}{l}\text { Descriptors of } \\
\text { the reasons }\end{array}$ \\
\hline $\begin{array}{l}\text { Reasons } \\
\text { for using }\end{array}$ & & $\begin{array}{l}\text { Using IWBs can easily get students' attention and help them } \\
\text { to concentrate on learning. }\end{array}$ & Attention \\
\hline & & $\begin{array}{l}\text { Using IWBs can help teachers explain complex and abstract } \\
\text { concepts. }\end{array}$ & Complex concepts \\
\hline & & $\begin{array}{l}\text { Using IWBs can help make teachers' teaching process } \\
\text { smoother and enhance teaching effectiveness. }\end{array}$ & Smooth teaching \\
\hline & & $\begin{array}{l}\text { IWBs do not produce chalk dust, so they are good for the } \\
\text { environment and human health. }\end{array}$ & $\begin{array}{l}\text { Environmental } \\
\text { benefit }\end{array}$ \\
\hline & & $\begin{array}{l}\text { Using IWBs can increase interactions between teachers and } \\
\text { students. }\end{array}$ & Interaction increase \\
\hline & & $\begin{array}{l}\text { Integrating IWBs into teaching can help teachers become } \\
\text { more flexible in using various classroom materials. }\end{array}$ & Flexible use \\
\hline $\begin{array}{l}\text { Reasons } \\
\text { for not }\end{array}$ & 1. & $\begin{array}{l}\text { School does not have enough funds to provide an IWB for } \\
\text { each classroom. }\end{array}$ & Lack of budget \\
\hline using & & $\begin{array}{l}\text { There is an IWB in my classroom that is not used due to lack } \\
\text { of time to design teaching materials. }\end{array}$ & Lack of time \\
\hline & & $\begin{array}{l}\text { There is an IWB in my classroom that is not used due to } \\
\text { limited sources of related teaching software. }\end{array}$ & Lack of sources \\
\hline & & $\begin{array}{l}\text { There is an IWB in my classroom that is not used due to lack } \\
\text { of professional training for the IWB's functions and operation. }\end{array}$ & Lack of training \\
\hline & & $\begin{array}{l}\text { There is an IWB in the classroom that is not used due to } \\
\text { frequent unsolved problems in using it. }\end{array}$ & $\begin{array}{l}\text { Frequency of } \\
\text { unsolved problems }\end{array}$ \\
\hline
\end{tabular}

There are also studies on how IWBs can direct students' increased engagement (Winzenried, Dalgarno \& Tinkler, 2010). However, students achieved different degrees of positive outcomes depending on the teacher (Glover et al., 2007). Effective teachers used various resources to keep students engaged on the tasks in most lessons, by providing immediate feedback to students' learning and by illustrating concepts and activities in a clear and visual approach (Hennessy, Wishart, et al., 2007; Reason 6). In their case studies, Winzenried et al. (2010) also found that teachers showed a wide range in ability to integrate IWBs into their teaching practices to engage students in learning. Glover et al. (2005) pointed out that the advantage of interactive electronic whiteboards is to increase interaction between teachers and students, as well as among students. When applying IWBs to teaching, teachers can use the storage and reappearance of information using functions such as "drag" to make explanations. Students can observe how their classmates interact with the electronic whiteboard, compare their own operational processes and experiences with those of others, and express the learning process, thereby increasing knowledge exchange and interaction among peers (Reason 5). 
On the other hand, researchers have also discussed the drawbacks of why it is difficult for teachers to use IWBs in their classrooms (Schmid, 2008; Slay et al., 2008; Smith et al., 2005). Cost constraints was one of the reasons for teachers not integrating IWBs in their teaching, as not all schools had enough funds for each classroom to be equipped with an IWB (Slay et al., 2008; Reason 1). Teachers could also lack ICT-competence in applying technological skills in various teaching and learning environments, as well as lack of ICT skills during their use of IWBs (Miller \& Glover, 2002; Slay et al., 2008; Reason 5). This echoes the finding of Smith et al. (2005), that the use of this technology is limited by a lack of adequate training for teachers, beyond the initial training provided by IWB companies and suppliers (Reason 4), and by the difficulty of physically locating the IWB in a classroom in order to optimise viewing by the whole class (Miller \& Glover, 2002; Reasons 3 and 4). Another difficulty teachers faced in using IWBs was in combining the use of this innovative technology tool with their existing teaching approaches (Schmid, 2008). Teachers also noted that they needed considerably more time to prepare for IWB lessons than for regular lessons (Miller \& Glover, 2002; Reason 2).

In the study, we used a survey, listing the reasons discussed previously, to collect data for examining elementary school mathematics and science teachers' use of IWBs in Taiwan as well as how they rated these reasons. We further analysed whether teachers' ratings on each reason were related to teaching subjects, teacher gender, and teaching experience, which have not been examined by prior empirical studies.

\section{Research questions}

For the purposes of the study, we proposed three research questions:

1. Why do elementary mathematics and science teachers use, or not use, IWBs?

2. Are there any significant differences in the reasons with respect to teaching subjects, teacher gender, or teaching experiences in the group using IWBs?

3. Are there any significant differences in the reasons related to teaching subjects, teacher gender, or teaching experiences in the group not using IWBs?

\section{Methodology}

\section{Developing the survey}

The survey consisted of two parts: the first to collect basic information about the teachers, and in the second part, reasons for using IWBs and not using IWBs (see Table 1 for the reasons). Table 1 also provides the short descriptors of the reasons to be used in Tables 2-5. The basic information part asked elementary school teachers for their teaching subjects, gender, teaching experience, and status in using IWBs. The questions in the second part of the survey were developed based on an overview of the discussions from prior research related to the benefits and drawbacks of using IWBs (see Table 1 for the identified reasons). There were six closed-ended questions for teachers who reported using IWBs, to rate them and one open-ended question for these teachers to provide other reasons, if any. After these there were five closedended questions for teachers who reported not using IWBs, to rate them and one openended question to illustrate any other reasons not listed in the survey. Participants rated the survey items in this section on a 3-point rating scale from 1 (Disagree) to 3 (Agree). Since each reason can explain an individual point for both benefits and drawbacks, each reason was rated separately. 


\section{Participants}

The survey was sent out to elementary schools randomly selected across Taiwan. Complete surveys were sent back to the researchers in a return envelope prepared for each school. The researchers received 863 surveys from elementary teachers of the selected schools. Excluding the cases with incomplete data and non-math and science teachers, there were 650 mathematics and science teachers from 52 elementary schools who remained in data analyses. Based on the purposes of the study, these participating teachers were divided into two groups, based on whether or not they used IWBs. The group of teachers who used IWBs consisted of $348(53.5 \%)$ elementary school teachers whereas the group of not using IWBs had 302 (46.5\%) elementary school teachers.

\section{Data analysis}

Percentages of each reason's ratings were computed (see Table 2). Independent samples t-test was conducted for the groups using IWBs and not using IWBs by teaching subjects and teacher gender, and ANOVA was performed for both groups according to teaching experience (see Tables 3-5).

\section{Results}

\section{Results from close-ended survey}

We computed the percentages for reasons of both using and not using IWBs on a rating scale ranging from 1 (Disagree) to 3 (Agree). The percentages for all reasons of using IWBs were high (see Table 2), indicating that most elementary school mathematics and science teachers who have used or are using IWBs in their teaching agreed with the reasons in the survey for why they chose to use IWBs. More elementary school teachers who reported not using IWBs appeared to agree only on reason $1(63.2 \%)$, indicating that the most important reason for them not to use IWBs was that there was no IWB equipment in their classroom.

Table 2: Percentages on reasons for using and not using IWBs

\begin{tabular}{|l|l|c|c|c|}
\hline \multicolumn{1}{|c|}{ Reasons } & Yes $(\%)$ & $\begin{array}{c}\text { Unknown } \\
(\%)\end{array}$ & No (\%) \\
\hline \multirow{4}{*}{$\begin{array}{l}\text { Use } \\
\text { reasons }\end{array}$} & Reason 1: Attention & 82.2 & 16.2 & 1.7 \\
\cline { 2 - 5 } & Reason 2: Complex concepts & 78.2 & 20.4 & 1.4 \\
\cline { 2 - 5 } & Reason 3: Smooth teaching & 76.4 & 21.3 & 2.3 \\
\cline { 2 - 5 } & Reason 4: Environmental benefit & 86.8 & 11.5 & 1.7 \\
\cline { 2 - 5 } & Reason 5: Interaction increase & 82.2 & 15.2 & 2.6 \\
\cline { 2 - 5 } & Reason 6: Flexible use & 87.6 & 11.2 & 1.1 \\
\hline \multirow{2}{*}{$\begin{array}{l}\text { Not use } \\
\text { reasons }\end{array}$} & Reason 1: Lack of budget & 63.2 & 20.5 & 16.2 \\
\cline { 2 - 5 } & Reason 2: Lack of time & 12.6 & 17.2 & 70.2 \\
\cline { 2 - 5 } & Reason 3: Lack of sources & 10.6 & 18.9 & 70.5 \\
\cline { 2 - 5 } & Reason 4: Lack of training & 14.6 & 17.2 & 70.2 \\
\cline { 2 - 5 } & Reason 5: Frequency of unsolved problems & 12.9 & 16.9 & 7.2 \\
\hline
\end{tabular}

According to a t-test for each reason by gender, Reasons 1 and 5 appeared to have significantly different results for male and female elementary teachers (see Table 3). This finding indicates that male teachers showed significantly higher ratings on the reason "Using IWBs can easily get students' attention and help them to concentrate on 
learning" than did female students. Additionally, male teachers' ratings on the reason "Using IWBs can increase interactions between teachers and students" were significantly higher than those of female teachers.

Within the group using IWBs, there were 243 mathematics teachers and 105 science teachers. No significant difference was found on the reasons for using IWBs between the two teaching subjects.

Table 3: Means, standard deviation, and $t$-test on use reasons by gender

\begin{tabular}{|l|c|c|c|c|c|}
\hline \multirow{2}{*}{\multicolumn{1}{c|}{ Reasons/Group }} & \multicolumn{2}{c|}{$\begin{array}{c}\text { Male } \\
(\mathrm{n}=117)\end{array}$} & \multicolumn{2}{c|}{$\begin{array}{c}\text { Female } \\
(\mathrm{n}=231)\end{array}$} & \multirow{2}{*}{$t$} \\
\cline { 2 - 5 } & $\mathrm{M}$ & $\mathrm{SD}$ & $\mathrm{M}$ & $\mathrm{SD}$ & \\
\hline Attention & 2.88 & .326 & 2.77 & .482 & $2.308^{*}$ \\
\hline Complex concepts & 2.79 & .426 & 2.75 & .471 & .804 \\
\hline Smooth teaching & 2.80 & .420 & 2.71 & .517 & 1.691 \\
\hline Environmental benefit & 2.89 & .316 & 2.83 & .439 & 1.265 \\
\hline Interaction increase & 2.88 & .351 & 2.75 & .506 & $2.434^{*}$ \\
\hline Flexible use & 2.91 & .321 & 2.84 & .398 & 1.457 \\
\hline \multicolumn{4}{|l|}{ Note: ${ }^{*} p<.05$}
\end{tabular}

As for teachers' teaching experience, Reasons 1, 2 and 3 appeared to be significant according to teachers' teaching experience (see Table 4). More experienced teachers tended to agree on the reasons "Using IWBs can easily get students" attention and help them to concentrate on learning" and "Using IWBs can help teachers explain complex and abstract concepts" than did novice teachers. Teachers with more teaching experience were also likely to agree on the reason "Using IWBs can help make teachers' teaching process smoother and enhance teaching effectiveness" than were teachers with only a few years of teaching experiences.

Table 4: Means, standard deviations and ANOVA on use reasons by teaching experiences

\begin{tabular}{|c|c|c|c|c|c|c|c|c|c|}
\hline \multirow[t]{2}{*}{ Reasons/Group } & \multicolumn{2}{|c|}{$\begin{array}{c}<5 \\
(n=26)\end{array}$} & \multicolumn{2}{|c|}{$\begin{array}{c}6-15 \\
(n=185)\end{array}$} & \multicolumn{2}{|c|}{$\begin{array}{c}16-25 \\
(n=103)\end{array}$} & \multicolumn{2}{|c|}{$\begin{array}{c}>26 \\
(n=34)\end{array}$} & \multirow[t]{2}{*}{$F$} \\
\hline & $\mathrm{M}$ & SD & $\mathrm{M}$ & SD & $\mathrm{M}$ & SD & $\mathrm{M}$ & SD & \\
\hline Attention & 2.58 & .578 & 2.79 & .456 & 2.83 & .398 & 2.94 & .239 & $3.718^{*}$ \\
\hline Complex concepts & 2.73 & .533 & 2.72 & .486 & 2.81 & .421 & 2.94 & .239 & $2.681^{*}$ \\
\hline Smooth teaching & 2.46 & .582 & 2.73 & .513 & 2.79 & .435 & 2.88 & .327 & $4.234^{* *}$ \\
\hline Envtl. benefit & 2.77 & .514 & 2.86 & .378 & 2.83 & .445 & 2.91 & .288 & .696 \\
\hline Interaction increase & 2.73 & .533 & 2.80 & .475 & 2.77 & .447 & 2.91 & .379 & 1.018 \\
\hline Flexible use & 2.88 & .326 & 2.85 & .397 & 2.86 & .372 & 2.91 & .288 & .252 \\
\hline
\end{tabular}

Note: ${ }^{*} p<.05,{ }^{* *} p<.01$

Regarding teachers who did not use IWBs, although mathematics teachers' rating scores were higher than science teachers, the t-test result indicated no significant differences. As for teachers' teaching experiences, results of ANOVA indicated no significant differences for each reason. For teachers not using IWBs, gender differences were found to be significantly different on Reasons 2 and 3 (see Table 5). Male elementary school teachers who do not use IWBs in their teaching showed higher ratings for the reasons that there is "lack of time to design teaching materials" and "limited sources for related teaching software" than did female elementary school teachers. 
Table 5: Means, standard deviation, and $t$-test on no use reasons by gender

\begin{tabular}{|l|c|c|c|c|c|}
\cline { 2 - 5 } \multicolumn{1}{c|}{} & \multicolumn{2}{c|}{$\begin{array}{c}\text { Male } \\
\text { Reasons / Group }\end{array}$} & \multicolumn{2}{c|}{$\begin{array}{c}\text { Female } \\
(\mathrm{n}=100)\end{array}$} & \multirow{2}{*}{$t$} \\
\cline { 2 - 5 } & $\mathrm{M}$ & $\mathrm{SD}$ & $\mathrm{M}$ & $\mathrm{SD}$ & \\
\hline Lack of budget & 2.41 & .818 & 2.50 & .728 & -.970 \\
\hline Lack of time & 1.54 & .784 & 1.37 & .657 & $2.024^{*}$ \\
\hline Lack of sources & 1.54 & .758 & 1.33 & .618 & $2.553^{*}$ \\
\hline Lack of training & 1.54 & .797 & 1.43 & .703 & 1.271 \\
\hline Frequency of unsolved problems & 1.51 & .745 & 1.39 & .691 & 1.428 \\
\hline Note: ${ }^{*} p<.05$ & \multicolumn{4}{|c}{}
\end{tabular}

\section{Other reasons for using or not using IWBs}

We also gathered responses to other reasons for using or not using IWBs reported by participating teachers in the survey. Most of the other reasons reported by the teachers for the use of IWBs could be categorised into the reasons in our survey. There was only one reason that was different from the reasons of the survey - the reason "the teacher used IWBs was because students showed positive reactions to his/her use of IWBs in teaching".

Some teachers reported other reasons for why they did not use IWBs. These reasons were: (1) Using IWBs consumes too much money and electricity and harms students' eyesight; (2) Using IWBs can cause light pollution; (3) It is inconvenient to use IWBs because they cannot be fixed in a classroom; (4) Some parents disagree with the use of IWBs because of the harm to their children's eyesight; (5) Teaching profession is the main goal and instructional equipment is just to assist teaching - too much dependence on using instructional tools can only result in students' interests and excitement about the technology itself; (6) Using IWBs can make teachers too dependent on the use of IWBs and ignore the guidance they need to provide for students during class time because the most effective way is to find students' mathematical misconceptions by their actual computations and then appropriately guide them to correct the misconceptions; and (7) There is too much sunlight in the classroom, which causes light reflection and makes using IWBs difficult.

\section{Discussion}

The findings of this study make significant contributions to the research on IWB use by examining elementary school teachers' perspectives on the reasons for using or not using IWBs in Taiwan, as well as whether each reason differs by teachers' teaching subject, gender, and teaching experience. The percentages of elementary school teachers' ratings for each reason in using IWBs were high. Most elementary school teachers who have used or are currently using IWBs agreed that using IWBs allows them to get students' attention and helps students concentrate; increases interactions between themselves and students; and helps them flexibly use various classroom materials. Additionally, the use of IWBs can help them explain complex and abstract concepts, make the teaching process smoother, and is good for the environment since it does not produce chalk dust. The results confirm the findings from prior empirical research related to advantages of using IWBs (Gillen et al., 2008; Glover et al., 2005, 2007; Holmes, 2009; Shenton \& Pagett, 2007).

Among the five reasons for not using IWBs, budget constraints appeared to be the most influential reason. This finding indicated that teachers who reported not using 
IWBs generally did not have an IWB in their classroom. This result is consistent with a previous empirical study that found cost constraints influenced the lack of IWBs in classroom and further influenced teachers to not use IWBs in their teaching (Slay et al., 2008). Although most teachers did not rate other reasons as important factors for them not to use IWBs, there were still more than ten percent of elementary school teachers reporting that they had an IWB in their classroom but they chose not to use it due to insufficient time for designing teaching materials and inadequate professional training for developing knowledge of IWB's functions and operation, shortage of related teaching software, and lack of knowledge in solving problems when using it. These results can provide information for policy makers and school administrators on whether teaching materials and software related to elementary school teachers' use of IWBs and teachers' knowledge in solving problems need to be addressed to help overcome these difficulties.

In the group of teachers using IWBs, each reason for use of IWBs by teaching subjects showed no significant differences, indicating that mathematics and science teachers who reported using IWBs rated the reasons similarly. Gender differences were found, in that male elementary teachers generally rated the reasons higher than did female teachers. Male elementary teachers' ratings for the using IWBs to get students' attention and helping students concentrate were significantly higher than ratings by female teachers. Male teachers also had significantly higher ratings for using IWBs to increase interactions between teachers and students. Gender differences have been found in teacher-student dyadic interactions (Jones \& Wheatley, 1990; She, 2000). Jones and Wheatley (1990) found that male science teachers asked more direct questions than did female teachers. She (2000) in her study concluded that teachers' beliefs can influence how they interact with their students. The prior empirical studies support the findings of the current study that male and female science teachers interacted differently with their students, and this difference may reciprocally influence the instructional approaches teachers use to get students' attention and help them concentrate. Teachers' gender differences in these areas may influence how teachers use technology to facilitate teaching effectiveness, however, from the current data of this study, how the male and female teachers differently used integrative pedagogical approaches with IWB for students' attention, concentration and interactions remains unknown. Therefore, more research is needed for further examination. The examination for differences of teachers' teaching experiences also explored the fact that experienced teachers showed significantly higher ratings for getting students' attention and helping students' concentration, helping explain complex and abstract concepts, and smoothing teaching process than did novice teachers.

Within the group not using IWBs, mathematics and science teachers generally rated each reason similarly. Experienced teachers also rated the reasons similar to novice teachers. However, male elementary teachers' ratings were significantly higher for the reasons of lacking time to design teaching materials and lacking related teaching software than were female teachers. The reasons why male and female teachers' ratings differed for the limited time use in designing classroom lessons and insufficient teaching software are unknown with current data from the study. Other methodological approaches, such as interviews, are needed to collect further in-depth data on potential differences of male and female teachers.

Around fifty-four percent of the elementary school mathematics and science teachers reported that they have used or are currently using IWBs in their teaching. This percentage was low, considering that this is the result after the promotion of IWB use 
by the Taiwan Ministry of Education (2008). Among the teachers who reported not using IWBs, the lack of an IWB in their classroom was the primary reason why they did not use IWBs. Therefore, to increase the percentage of use IWBs in elementary classrooms, policy makers in Taiwan need to allot more funds to schools so they can purchase more IWBs that are easily accessible for teachers.

The other reasons teachers reported that weres not listed in the survey included pollution, harm to children's eyesight, parents' opinions, belief in the teaching professions, disadvantages of natural classroom settings, and avoidances of being too dependent on IWB use. From viewing these self-reported reasons, some teachers may lack a clear and overall understanding of how IWBs can serve as a facilitating tool in their teaching, and not a tool to put an extra burden on their current teaching. They may not know that an IWB is a technical tool to allow teachers to integrate this device into their current pedagogical approaches, thereby enhancing their teaching effectiveness and students' understanding in learning as the ultimate outcomes. IWBs are not employed for teachers to abandon their current pedagogical approaches and replace them with new pedagogical approaches that integrate the use of IWBs. However, it requires a gradual process for assimilating their current pedagogical approaches with IWBs (Beauchamp, 2004; Winzenried et al., 2010). Lai (2010) studied school teachers' perceptions in training workshops for the use of IWBs in Taiwan and found that these teachers perceived the importance of providing school teachers with training programs and a platform for continual development and exchanging ideas. To help school teachers be more willing to use IWBs, policy makers, school teachers, researchers, and representatives of companies publishing teaching and software materials should hold open forums for continuing communications to encourage elementary school teachers to use IWBs, and remedying any inaccurate understanding of the use of IWBs.

There is also the possibility that each school has its individual culture and perspectives on the use of IWBs. Sutherland et al. (2004) suggested that each classroom setting needs to be considered as a separate socio-cultural environment in which teachers need to choose appropriate ICT tools to suit the subject contents, so the integrative process can reach its optimum aims. The use of IWBs may differ in different schools and classrooms, as support with available sources for teaching materials and related software and professional training may vary in different contexts, resulting in varying teachers' use of IWBs in their pedagogy and in different domains. Therefore, future research with experimental research design is needed to examine whether teachers in different school cultures use different pedagogical integrative approaches with IWBs as well as in different domains.

\section{Implications and future research}

This study provides several insights for future research. More in-depth research is needed to examine whether male and female elementary school teachers use different pedagogical approaches for integrating IWBs into their teaching. Additionally, how experienced and novice teachers differ in their integrative skills in using IWBs is still unclear in current research. More research to explore what specific pedagogical strategies teachers employ during their use of IWBs in different academic domains is also needed since researchers have found that although the IWB is unique in its functions to improve teaching effectiveness, teachers can use it as a general whiteboard (Northcote, Mildenhall, Marshall \& Swan, 2010). 
The study also provides policy makers in Taiwan information about elementary school mathematics and science teachers' use of IWBs and the reasons involved in using or not using IWBs. By analysing the reasons, schools can be helped to budget for purchasing more IWBs, so elementary school mathematics and science teachers can continue developing their pedagogical approaches by integrating IWBs into their teaching to put the goals (i.e., promoting teaching effectiveness through the use of IWBs) into practice.

\section{References}

Arnott S. (2004). Computers to replace school blackboards. Computing, 9 August. [verified 27 Oct 2012] http: / / www.computing.co.uk/ctg/news / 1860992/ computers-replace-schoolblackboards

Beauchamp, G. (2004). Teacher use of the interactive whiteboard in primary schools: Towards an effective transition framework. Technology, Pedagogy and Education, 13(3), 327-348. http: / / dx.doi.org/10.1080/14759390400200186

Beauchamp, G. \& Parkinson, J. (2005). Beyond the 'wow' factor: Developing interactivity with the interactive whiteboard. School Science Review, 86(316), 97-103. http: / / arrts.gtcni.org.uk/gtcni/ bitstream/2428/49478/1/ beyond+the+wow+factor.pdf

Chou, C. (2003). Interactivity and interactive functions in web-based learning systems: A technical framework for designers. British Journal of Educational Technology, 34(3), 265-279. http: / / dx.doi.org/10.1111/1467-8535.00326

Da Ponte, J. P., Oliveira, H. \& Varandas, J. M. (2002). Development of pre-service mathematics teachers' professional knowledge and identity in working with information and communication technology. Journal of Mathematics Teacher Education, 5(2), 93-115. http: / / dx.doi.org/10.1023/ A:1015892804607

Gillen, J., Littleton, K., Twiner, A., Staarman, J. \& Mercer, N. (2008). Using the interactive whiteboard to resource continuity and support multimodal teaching in a primary science classroom. Journal of Computer Assisted Learning, 24(4), 348-358. http: / / dx.doi.org/10.1111/j.1365-2729.2007.00269.x

Glover, D., Miller, D., Averis, D. \& Door, V. (2005). The interactive whiteboard: A literature survey. Technology, Pedagogy and Education, 14(2), 155-170. http:/ / dx.doi.org/10.1080/14759390500200199

Glover, D., Miller, D., Averis, D. \& Door, V. (2007). The evolution of an effective pedagogy for teachers using the interactive whiteboard and modern languages: An empirical analysis from the secondary sector. Learning, Media and Technology, 32(1), 5-20. http: / / dx.doi.org/10.1080/17439880601141146

Hakkarainen, K., Muukonen, H., Lipponeni, L., Ilomaki, L., Rahikainen, M. \& Lehtinen, E. (2001). Teachers' information and communication technology (ICT) skills and practices of using ICT. Journal of Technology and Teacher Education, 9(2), 181-197. http:// www.editlib.org/p/8427

Hall, I. \& Higgins, S. (2005). Primary school students' perceptions of interactive whiteboards. Journal of Computer Assisted Learning, 21(2), 102-117. http: / / dx.doi.org/10.1111/j.13652729.2005.00118.x

Hennessy, S., Deaney, R., Ruthven, K. \& Winterbottom, M. (2007). Pedagogical strategies for using the interactive whiteboard to foster learner participation in school science. Learning, Media and Technology, 32(3), 283-301. http:/ / dx.doi.org/10.1080/17439880701511131 
Hennessy, S., Wishart, J., Whitelock, D., Deaney, R., Brawn, R., la Velle, L., McFarlane, A., Ruthven, K. \& Winterbottom, M. (2007). Pedagogical approaches for technology-integrated science teaching. Computers \& Education, 48(1), 137-152. http: / / dx.doi.org/10.1016/j.compedu.2006.02.004

Higgins, S., Beauchamp, G. \& Miller, D. (2007). Reviewing the literature on interactive whiteboards. Learning, Media and Technology, 32(3), 213-225. http: / / dx.doi.org/10.1080/17439880701511040

Holmes, K. (2009). Planning to teach with digital tools: Introducing the interactive whiteboard to pre-service secondary mathematics teachers. Australasian Journal of Educational Technology, 25(3), 351-365. http: / / www.ascilite.org.au/ajet/ajet25/holmes.html

Jang, S.-J. (2009). Exploration of secondary students' creativity by integrating web-based technology into an innovative science curriculum. Computers $\mathcal{E}$ Education, 52(1), 247-255. http:/ / dx.doi.org/10.1016/j.compedu.2008.08.002

Jang, S.-J. (2010). Integrating the interactive whiteboard and peer coaching to develop the TPACK of secondary science teachers. Computers E Education, 55(4), 1744-1751. http:/ / dx.doi.org/10.1016/j.compedu.2010.07.020

Jang, S.-J. \& Tsai, M.-F. (2012). Exploring the TPACK of Taiwanese elementary mathematics and science teachers with respect to use of interactive whiteboards. Computers $\mathcal{E}$ Education, 59(2), 327-338. http: / / dx.doi.org/10.1016/j.compedu.2012.02.003

Jones, M. G. \& Wheatley, J. (1990). Gender differences in teacher-student interactions in science classrooms. Journal of Research in Science Teaching, 27(9), 861-874. http: / / dx.doi.org/10.1002/ tea.3660270906

Kennewell, S., Tanner, H., Jones, S. \& Beauchamp, G. (2008). Analysing the use of interactive technology to implement interactive teaching. Journal of Computer Assisted Learning, 24(1), 6173. http: / / dx.doi.org/10.1111/j.1365-2729.2007.00244.x [also at http:/ / heartlandinteractive tech.pbworks.com/f/Analyzing $\% 2 \mathrm{Bthe} \%$ 2BUse $\%$ 2Bof $\%$ 2BInteractive $\% 2 \mathrm{BTechnology} . \mathrm{pdf}]$

Lai, H. (2010). Secondary school teachers' perceptions of interactive whiteboard training workshops: A case study from Taiwan. Australasian Journal of Educational Technology, 26(4), 511-522. http: / / www.ascilite.org.au/ajet/ ajet26/lai.html

Lopez, O. S. (2010). The digital learning classroom: Improving English language learners' academic success in mathematics and reading using interactive whiteboard technology. Computers \& Education, 54(4), 901-915. http:/ / dx.doi.org/10.1016/j.compedu.2009.09.019

Murcia, K. (2008). Teaching for scientific literacy with an interactive whiteboard. Teaching Science, 54(4), 17-21. [verified 27 Oct 2012] http:/ / smartboardita.pbworks.com/f/ Teaching\%2Bfor $\%$ 2Bscientific $\% 2 \mathrm{~B} \%$ 2Bliteracy $\% 2 \mathrm{~B}$ with $\% 2 \mathrm{Ban} \% 2 \mathrm{~B} \%$ 2Binteractive $\% 2 \mathrm{~B}$ whiteboard.pdf

Murcia, K. \& Sheffield, R. (2010). Talking about science in interactive whiteboard classrooms. Australasian Journal of Educational Technology, 26(4), 417-431. http: / / www.ascilite.org.au/ajet/ajet26/ murcia.html

Taylor, M., Harlow, A. \& Forret, M. (2010). Using a computer programming environment and an interactive whiteboard to investigate some mathematical thinking. Procedia-Social and Behavioral Sciences, 8, 561-570. http: / / dx.doi.org/10.1016/j.sbspro.2010.12.078

Merrett, S. \& Edwards, J. (2005). Enhancing mathematical thinking with an interactive whiteboard. Micromath, 21(3), 9-12. [verified 27 Oct 2012] http: / / eprints.soton.ac.uk/19646/1/ eprints_version.pdf 
Ministry of Education (2008). Whitepaper for educational technology in K-12 education from 2008 to 2011. Taiwan: Ministry of Education.

Miller, D. \& Glover, D. (2002). The interactive whiteboard as a force for pedagogic change: The experience of five elementary schools in an English education authority. Information Technology in Childhood Education Annual, 2002, 5-19. http: / / www.editlib.org/p/10762 [also at http: / / www.highbeam.com/doc/1G1-91564847.html]

Miller, D., Glover, D. \& Averis, D. (2005). Developing pedagogic skills for the use of the interactive whiteboard in mathematics. British Educational Research Association, Glamorgan. http:// www.keele.ac.uk/media/keeleuniversity/fachumsocsci/sclpppp/education/ interactivewhiteboard / BERA\%20Paper\%20Sep\%202005.pdf

Northcote, M., Mildenhall, P., Marshall, L. \& Swan, P. (2010). Interactive whiteboards: Interactive or just whiteboards? Australasian Journal of Educational Technology, 26(4), 494-510. http:/ / www.ascilite.org.au/ajet/ajet26/ northcote.html

Schmid, E. C. (2008). Potential pedagogical benefits and drawbacks of multimedia use in the English language classroom equipped with interactive whiteboard technology. Computers $\mathcal{E}$ Education, 51(4), 1553-1568. http: / / dx.doi.org/10.1016/j.compedu.2008.02.005

She, H.-C. (2000). The interplay of a biology teacher's beliefs, teaching practices and genderbased student-teacher classroom interaction. Educational Research, 42(1), 100-111. http: / / dx.doi.org/10.1080/001318800363953

Shenton, A. \& Pagett, L. (2007). From "bored" to screen: The use of the interactive whiteboard for literacy in six primary classrooms in England. Literacy, 41(3), 129-136. http: / / dx.doi.org/10.1111/j.1467-9345.2007.00475.x

Slay, H., Sieborger, I. \& Hodgkinson-Williams, C. (2008). Interactive whiteboards: Real beauty or just "lipstick"? Computers $\mathcal{E}$ Education, 51, 1321-1341. http: / / dx.doi.org/10.1016/j.compedu.2007.12.006

Smith, F., Hardman, F. \& Higgins, S. (2006). Impact of interactive whiteboards on teacher-pupil interaction in the national literacy and numeracy strategies. British Educational Research Journal, 32(3), 443-457. http: / / dx.doi.org/10.1080/01411920600635452

Smith, H. J., Higgins, S., Wall, K. \& Miller, J. (2005). Interactive whiteboards: Boon or bandwagon? A critical review of the literature. Journal of Computer Assisted Learning, 21(2), 91101. http:/ / dx.doi.org/10.1111/j.1365-2729.2005.00117.x

Sutherland, R., Armstrong, V., Barnes, S., Brawn, R., Breeze, N., Gall, M., Matthewman, S., Olivero, F., Taylor, A., Triggs, P., Wishart, J. \& John, P. (2004). Transforming teaching and learning: Embedding ICT into everyday classroom practices. Journal of Computer Assisted Learning, 20(6), 413-425. http: / / dx.doi.org/10.1111/j.1365-2729.2004.00104.x

Torff, B. \& Tirotta, R. (2010). Interactive whiteboards produce small gains in elementary students' self-reported motivation in mathematics. Computers $\mathcal{E}$ Education, 54(2), 379-383. http: / / dx.doi.org/10.1016/j.compedu.2009.08.019

Wall, K., Higgins, S., \& Smith, H. (2005). 'The visual helps me understand the complicated things': Pupil views of teaching and learning with interactive whiteboards. British Journal of Educational Technology, 36(5), 851-867. http:/ / dx.doi.org/10.1111/j.1467-8535.2005.00508.x

Warwick, P. \& Kershner, R. (2008). Primary teachers' understanding of the interactive whiteboard as a tool for children's collaborative learning and knowledge-building. Learning, Media and Technology, 33(4), 269-287. http: / / dx.doi.org/10.1080/17439880802496935 
Warwick, P., Mercer, N., Kershner, R. \& Staarman, J. K. (2010). In the mind and in the technology: The vicarious presence of the teacher in pupil's learning of science in collaborative group activity at the interactive whiteboard. Computers $\mathcal{E}$ Education, 55(1), 350362. http:/ / dx.doi.org/10.1016/j.compedu.2010.02.001

Winzenried, A., Dalgarno, B. \& Tinkler, J. (2010). The interactive whiteboard: A transitional technology supporting diverse teaching practices. Australasian Journal of Educational Technology, 26(4), 534-552. http:/ / www.ascilite.org.au / ajet/ ajet26/ winzenried.html

Authors: Professor Syh-Jong Jang and Meng-Fang Tsai

Graduate School of Education, Chung-Yuan Christian University

200 Chung Pei Road, Chung Li City 32023, Taiwan

Email: jang@cycu.edu.tw, tsaim@cycu.edu.tw Web: http: / / www.cycu.edu.tw /

Please cite as: Jang, S.-J. \& Tsai, M.-F. (2012). Reasons for using or not using interactive whiteboards: Perspectives of Taiwanese elementary mathematics and science teachers. Australasian Journal of Educational Technology, 28(8), 1451-1465.

http:/ / www.ascilite.org.au/ajet/ajet28/jang.html 